\title{
Development of the Optimum Composition of Organic Liquid Fertilizer
}

\author{
Hartomo Soewardi and Raizsa Laksmita
}

\begin{abstract}
Organic Liquid Fertilizer is a liquid made from the decomposition of organic material such as plant residue and animal waste in which its content is more than one nutrient. The advantages of this fertilizer are to resolve a deficiency of nutrient and provide the additional nutrients quickly. Most of the liquid organic fertilizers sold in the market are inappropriate with the national standard of agriculture in Indonesia that is in value range 4 to 9 of the potential of Hydrogen (pH). Majority of the existing fertilizer contains the pH value of less than 4 or higher than 9. It means these fertilizers are too sour and overly bases. This condition hampers the plant growth. Thus, it is necessary to supply the proper fertilizer. This study primarily aims to develop the optimum composition of the organic liquid fertilizer that satisfies the national standard of Indonesian agriculture. Taguchi method was used to design the optimal composition and experimental study was conducted to determine a value of Signal Noise Ratio as well as to validate the best composition. Statistical analysis by using t-test was done to test the hypothesis. The result of this study shows that the new composition of organic liquid fertilizer is valid to satisfy the national standard of $\mathbf{p H}$ value that is 7 . Thus, it is known that the optimum composition encompassing A1 is the cow urine with $1000 \mathrm{ml}, \mathrm{B3}$ is the probiotic with $6 \mathrm{ml}$, $\mathrm{C1}$ is the goat dung with $\mathbf{5 0 0}$ grams, and D3 is the spices with 30 grams (A1-B3-C1-D3).
\end{abstract}

Index Terms-Design experiment, organic liquid fertilizer, pH value, taguchi method.

\section{INTRODUCTION}

Generally, the soil is able to supply sufficient nutrients to the plant which contributes to its growth. However, the excessive toxicity contained in a soil can hamper the growth of plant roots. It is because the plant may not obtain some nutrients adequately [1]. Subsequently, in [1] stated that if such condition happens for a prolonged period, it will lead to the nutrient deficiency symptoms on the plant which can cause a problem of fewer nutrients. Thus, it is advised that farmers provide extra nutrients by means of the artificial fertilizer to improve the fertility of the soil.

Liquid organic fertilizer is one type of artificial fertilizer that is derived from living organism [2] and can be soluble easily in the soil as well as contains some important particles for growing the plant [3]. This fertilizer has not been fully used by farmers who still depend on the chemical fertilizers which can acidify the soil and cause irreparable damage [4]. As for [5] expresses that the compact organic fertilizer such as manure and compost has also left with some disadvantage such as their low density and low nutrient content. While

\footnotetext{
Manuscript received April 8, 2018; revised May 25, 2018.
}

Hartomo Soewardi and Raizsa Laksmita are with Universitas Islam Indonesia, Indonesia (e-mail: hartomo@uil.ac.id, 13522169@students.uii.ac.id). advantages of liquid organic fertilizer, according to [3] and [5], can improve the physical properties, chemical properties, and biological properties of the soil as well as it leads to faster nutrient supply than compact organic fertilizers do.

However, the composition of organic liquid fertilizer must comply with a national standard. The regulation of minister for agriculture in Indonesia (2011) stated that Organic liquid fertilizer should contain 4 to 9 of $\mathrm{pH}$. [6] explains that $\mathrm{pH}$ value in those range will increase solubility of the macronutrients such as nitrogen, Phosphorous, Calcium, Potassium, Magnesium, and Sulphur. Conversely it decreases nutrient availability, microbial activity, and solubility as well as increases aluminum ion toxicity which influences fertilizer efficiency, plant growth, and absorption.

In fact, most of the existing organic liquid fertilizer contains the $\mathrm{pH}$ value which still has not met the standard. It is primarily because they are less than 4 or higher than 9. It indicates that the fertilizer is too acid and base in the soil. Thus, this condition requires a re-development of the raw material composition of fertilizer to better.

There are many previous researches which have been conducted about the organic liquid fertilizer such as the study investigated about the effect of different rate of organic fertilizers on broccoli [7] and [8] study about use of technology to process phosphate waste to establish additive in liquid complex fertilizer. Meanwhile, [9] studied to develop solid organic fertilizer.

The objective of this study is to develop optimum composition of the organic fertilizer based on the $\mathrm{pH}$ value using Taguchi method.

\section{RESEARCH METHOD}

\section{A. Field Study}

Field study is conducted to identify some symptoms of problems by direct measuring $\mathrm{pH}$ value of the existing liquid fertilizer sold in the market. Five samples of the liquid organic fertilizer were taken in the selected market.

\section{B. Apparatus}

In this research some equipment was used. They were as follows:

- Digital $\mathrm{pH}$ meter is used to measure $\mathrm{pH}$ value.

- Aqua Dest is a liquid to clean up the pH meter

- Ms. Excel software 2010 is used to calculate the signal noise ratio, ANOVA calculation, normality and homogeneous test.

\section{Experimental Study}

1) Object of research

This study focuses on developing the optimal composition 
of the organic liquid fertilizer based on potential Hydrogen value.

\section{2) Design of experiment}

Design of experiment in this study refers to Taguchi method which follows the following procedure below.

- Determining control factor. Control factor is factor that can be controlled by the manufacturer and cannot be changed directly by the customer.

- Determining the degree of freedom. Degree of freedom need to get the total minimum of experiment and orthogonal array.

- Determining orthogonal array. According to [10], Dr. Genichi Taguchi uses orthogonal array to determine the variation. Thus, an L9 orthogonal array is used in this study.

\section{Statistical Analysis}

In this study statistical analysis consist of

\section{1) Normality test}

In statistics, Normality test is used to determine whether a data set is well-modeled by a normal distribution and to compute how likely it is for a random variable underlying the data set to be normally distributed. The collected data should be normal. The formula of normality test below is

$$
x^{2}=\sum_{i-1}^{k}\left(\frac{O i-E i}{E i}\right)
$$

where:

Oi: observed frequency

Ei: expected frequency for $\mathrm{i}$-th cell

The data are normally distributed if $X^{2}$ calculation is $\leq X^{2}$ Table. The $X^{2}$ table in this study is 7.814 .

\section{2) Homogeneity test}

The collected data should be homogeneous. The homogenity test is aimed to know the homogeneous data when the elements of the population studied have relatively uniform properties with each other. The formula of homogenity test below is

$$
x^{2}=(1 n 10)\left(B-\sum(n i-1) \log S_{i}^{2}\right)
$$

where:

$S^{2}=$ Combined variance of all samples

The data are homogenous if $\mathrm{X}^{2}$ calculation $\leq \mathrm{X}^{2}$ table. The $X^{2}$ table in this study is 5.991

\section{3) ANOVA calculation}

Anova calculation is used to determine whether there is influence between the factors that have been determined against the response varible $\mathrm{pH}$. The formula of Anova below is

$$
\begin{gathered}
\rho \quad=\left(\frac{S S^{\prime}}{S T}\right) \times 100 \% \\
S S^{\prime}=S S-(S S E \times D F) \\
S T=\sum y 2
\end{gathered}
$$

where:

\section{$\rho:$ contribution percentage \\ SS' : pure of square \\ ST : Total Sum of Square \\ DF : Degree of freedom}

4) Signal noise to ratio

Ref. [11] argued that Taguchi measured the variation present by creating the transformation of repetition data to another value. Signal to Noise Ratio is the transformation. Signal to Noise Ratio Nominal is best used for determining the optimum composition of organic liquid fertilizer. This calculation determines the optimum composition of making organic liquid fertilizer

$$
\begin{array}{cl}
S N R_{N T B}= & 10 \log 10\left(\frac{\mu^{2}}{\sigma^{2}}\right) \\
\mu & =\frac{1}{n} \sum_{i=1}^{n} y i \\
\sigma^{2} & =\frac{1}{n} \sum_{i=1}^{n}(y i-\mu)^{2}
\end{array}
$$

where:

$\mathrm{n}$ : number of tests in the experiment (trial)

yi: response value for each replication

5) Independent t-test

Experiment confirmation of experiment is for comparing the $\mathrm{pH}$ value data before and after recommendation condition to see whether there is any differences or not. In this study use independent $t$-test. Independent $t$-test is the test that evaluates the difference between the means of two independent or unrelated groups. It is commonly referred to as a between-group design, and can be used for analyzing a control and experimental group [12]. The formula of independent $t$-test below is

$$
\begin{gathered}
t=\frac{\overline{X 1}-\overline{X 2}}{\sqrt{\frac{\left(n_{1}-1\right) S_{1}{ }^{2}+\left(n_{2}-1\right) n_{2}{ }^{2}}{n_{1}+n_{2}-2}\left(\frac{1}{n_{1}}+\frac{1}{n_{2}}\right)}} \\
s=\sqrt{\frac{\sum_{i=1}^{n}\left(X_{i}-\bar{x}\right)^{2}}{n-1}}
\end{gathered}
$$

where:

$$
\begin{aligned}
& \mathrm{X}: \text { Data Value } \\
& \mathrm{n}: \text { Total of data } \\
& \mathrm{S}: \text { Standard Deviation } \\
& \mathrm{df}: \text { Degree of Freedom }
\end{aligned}
$$

\section{RESUlt AND DisCUSSION}

\section{A. Result of Experiment}

Control factor of this experiment can be shown in the Table I

TABLE I: CONTROL FACTOR

\begin{tabular}{ccccc}
\hline \hline \multirow{2}{*}{ No } & \multirow{2}{*}{ Factors } & \multicolumn{3}{c}{ Level } \\
\cline { 3 - 5 } & & Level 1 & Level 2 & Level 3 \\
\hline 1 & Cow urine & $1000 \mathrm{ml}$ & $800 \mathrm{ml}$ & $600 \mathrm{ml}$ \\
\hline 2 & Probiotic EM4 & $10 \mathrm{ml}$ & $8 \mathrm{ml}$ & $6 \mathrm{ml}$ \\
\hline 3 & Dung & $500 \mathrm{gram}$ & $400 \mathrm{gram}$ & $300 \mathrm{gram}$ \\
\hline 4 & Spices & $50 \mathrm{gram}$ & $40 \mathrm{gram}$ & $30 \mathrm{gram}$ \\
\hline \hline
\end{tabular}


These factors consist of three levels that is level 1, level 2, and level 3 for experimental study. The cow urine factor utilizes the sample of $1000 \mathrm{ml}$ for level $1,800 \mathrm{ml}$ for level 2, and $600 \mathrm{ml}$ for level 3. It is meant to determine in which one is the most appropriate for content of cow urine among others for each trial. Probiotic Em4 factor uses sample of $10 \mathrm{ml}$ for level 1, $8 \mathrm{ml}$ for level 2, and $6 \mathrm{ml}$ for level 3 . It is meant to determine which one is the most appropriate for content of probiotic EM4 among them for each trial. The dung factor utilizes 500 gram for level 2, 400 gram for level 2 and 300 gram for level 3. It is intended to determine which is the most appropriate for dung processing between them for each trial. As the same goes with spices factor, 50 gram for level 1, 40 gram for level 2 and 30 gram for level 3. It also determines appropriate for content spices among them for each trial.

This study has four factors and three levels. The formula of degree of freedom below is

Degree of Freedom $=($ Total of factor $) \times($ total of level- 1$)$

$=4 \times(3-1)$

$=8$ degree of freedom

where:
A: Cow urine
B: Probiotic Em4

C: Dung

D: Spices

TABLE II: RESULT OF EXPERIMENT OF PH VALUE

\begin{tabular}{|c|c|c|c|c|c|c|c|}
\hline \multicolumn{5}{|c|}{ Inner Array } & & & \\
\hline \multirow{3}{*}{ Trial } & $\mathbf{A}$ & B & $\mathbf{C}$ & D & \multicolumn{3}{|c|}{ Experiment Data (pH) } \\
\hline & \multicolumn{4}{|c|}{ Colomn Number } & & & \\
\hline & 1 & 2 & 3 & 4 & Y1 & Y2 & Y3 \\
\hline 1 & 1 & 1 & 1 & 1 & 7.6 & 7.5 & 7.6 \\
\hline 2 & 1 & 2 & 2 & 2 & 7.5 & 7.6 & 7.7 \\
\hline 3 & 1 & 3 & 3 & 3 & 7.7 & 7.7 & 7.6 \\
\hline 4 & 2 & 1 & 2 & 3 & 7.6 & 7.8 & 7.8 \\
\hline 5 & 2 & 2 & 3 & 1 & 7.6 & 7.4 & 7.4 \\
\hline 6 & 2 & 3 & 1 & 2 & 8.1 & 8 & 8 \\
\hline 7 & 3 & 1 & 3 & 2 & 7.7 & 7.5 & 7.5 \\
\hline 8 & 3 & 2 & 1 & 3 & 6.8 & 6.9 & 6.9 \\
\hline 9 & 3 & 3 & 2 & 1 & 8 & 8.1 & 8 \\
\hline
\end{tabular}

The suitable orthogonal array should be the same or more than that with the degree of freedom [13]. Because the degree of freedom is 8 but in the standard orthogonal array there are four factors and three levels, it should choose L9. Therefore, it chooses L9 $\left(3^{4}\right)$ with the minimum experiment of 9. Choosing the orthogonal array based on the standard of orthogonal array. Once completing an experiment, the researcher shall get the data of $\mathrm{pH}$ value. The data of $\mathrm{pH}$ value from the experiment can be shown in the Table II.

$\mathrm{PH}$ values in Table II are resulted from the smallest value of 6.8 and the largest value of 8.1. This research does 3 replications to decrease the error. Minimum to do replication is three.

\section{B. Normality Test}

This study use excels for calculating the normality test. The data is normal if the $X_{2}$ calculation is less than $X 2$ Table III
TABLE III: RESULT OF NORMALITY TEST

\begin{tabular}{cc}
\hline \hline$\chi^{2}$ table & 7.814727903 \\
\hline$\chi^{2}$ calculation & 5.964740589 \\
\hline Conclusion & NORMAL \\
\hline \hline
\end{tabular}

Based on Table III. It is possible to conclude that the data is normal; Ho is accepted because the $X^{2}$ calculation $<X^{2}$ table. It gets the $X^{2}$ table that is 7.814 is more than 5.964 . Therefore, it is assumed that the populations from where the samples of $\mathrm{pH}$ value are collected are normally distributed. The data should be normal because the requirement of ANOVA has criteria such as the data must be normal and homogeneous.

\section{Homogeneity Test}

In this study, homogeneous test was conducted by using excel. In homogeneity test, if the value of $X^{2}$ calculation $<X^{2}$ table, the data is homogeneous. The result of homogeneity test can be shown in the Table IV.

TABLE IV: RESULT OF HOMOGENEITY TEST

\begin{tabular}{cc}
\hline$\chi^{2}$ Calculation & -52.0131784 \\
\hline$\chi^{2}$ table & 5.99146455 \\
\hline Conclusion & HOMOGENEOUS \\
\hline \hline
\end{tabular}

Based on the Table IV, it is revealed that the $\mathrm{X}^{2}$ calculation is less than that of X2 table. Therefore, it gets $-52.013<5.991$ which means that the data is homogenous. In other words, the population data of $\mathrm{pH}$ value has some relatively uniform properties with one another. Homogeneity tests should be performed because the data criterion before the ANOVA test is that the data should be homogeneous and normal [14].

\section{Anova Calculation}

On the basis of ANOVA calculation, it is possible to conclude the contribution of each factor. It can be shown in the Table V.

TABLE V: RESUlT OF ANOVA TEST FOR CONTRIBUTION FACTOR (\%)

\begin{tabular}{cccccccc}
\hline $\begin{array}{c}\text { Source of } \\
\text { Variance }\end{array}$ & $\mathbf{D}$ & SS & MS & F cal & $\begin{array}{c}\mathbf{F} \\
\text { Table }\end{array}$ & SS & $\begin{array}{c}\text { Contri } \\
\text { bution } \\
(\%)\end{array}$ \\
\hline Factor A & 2 & 0.294 & 0.147 & 19.850 & 3.554 & 0.28 & 0.093 \\
\hline Factor B & 2 & 1.621 & 0.810 & 109.400 & 3.554 & 1.61 & 0.536 \\
\hline Factor C & 2 & 0.436 & 0.218 & 29.450 & 3.554 & 0.42 & 0.140 \\
\hline Factor D & 2 & 0.510 & 0.255 & 34.400 & 3.554 & 0.49 & 0.165 \\
\hline Residual & 1 & 0.13 & 0.007 & & 0.19 & 0.064 \\
\hline Total & 2 & 2.99 & \multicolumn{7}{c}{ TOTAL } & $\mathbf{1}$ \\
\hline \hline
\end{tabular}

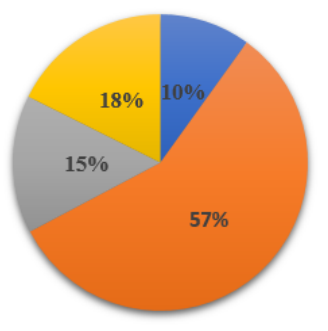

"Cow Urine $\quad \approx$ Probiotic Em4 $\quad$ Goat Dung $=$ Spices

Fig. 1. Contribution control factor (\%)

Based on Table $\mathrm{V}$, the result of contribution is revealed. 
The factors that have the contribution from respectively from the highest to the lowest are factor B (Probiotic Em4) with $0.536 \%$, factor D (spices) with $0.165 \%$, Factor C (goat dung) with $0.140 \%$, and factor A (cow urine) with $0.093 \%$. Factor $\mathrm{B}$ gives the highest contribution of the $\mathrm{pH}$ value on making organic liquid fertilizer. These four factors have an influence on the $\mathrm{pH}$ value because $\mathrm{F}$ calculation is more than $\mathrm{F}$ table.

Based on the graph, it can be conclude that probiotic Em4 has the highest contribution factor for the $\mathrm{pH}$ value and followed by spices, goat dung, and cow urine.

- Probiotic has the highest contribution because fermentation is the most important process in this process. It is the process of decomposition of organic compounds to produce energy and substitution of the substrate into new products by microbes [15]. The fermentation process is strongly influenced by bacterial activity. EM4 is a variety of one type of solution containing bacteria, among others, decomposer bacteria that serves as decomposers of organic materials naturally in the soil. Bacterial activity greatly affects $\mathrm{pH}$.

- The second contribution is spices because the manufacture of liquid organic fertilizer consists of temulawak, galangal, red chili, turmeric, onion, and garlic. Meanwhile, spice herbs have different nutrients or ingredients. This content is a nutritional supplement of liquid organic fertilizer. Complement in nutrients, killing of soil pathogens, and others, for example chili. The hot chili of a substance called capsaisin is the content contained in chili. The heat on the chili is caused by this substance. Capsaicin is contained in chili seeds. Capsaicin function in chili is as a calculation tool from the attack of predators and fungus attacks. Due to hot and spicy chili, the predator will not eat it. If the fungus is exposed to capsaicin, the growth of the fungus can be disrupted. Spice herbs have different $\mathrm{pH}$ on each ingredient. Different types of spices have different decay. Decomposition of each material is different so it causes changes. $\mathrm{pH}$ on spices cause $\mathrm{pH}$ changes in liquid organic fertilizer during the fermentation process.

- The third contribution is dung because based on the research before, [16] it is stated that the long time of fermentation process influences the $\mathrm{pH}$ value. The $\mathrm{pH}$ value is influenced by the nitrogen content on the fertilizer. In the beginning of fermentation process the process formation of ammonia from nitrogen-containing the compound occurs. The nitrogen compound is derived from goat dung. Goat dung is rich in nitrogen, which is based on [17] goat dung has the nitrogen content of $21.8 \mathrm{lb} / \mathrm{ton}$. It is this nitrogen content that causes the change of $\mathrm{pH}$ value. It causes the increase of $\mathrm{pH}$. In the process of fermentation, acid release happened, which causes decrease of $\mathrm{pH}$ value. The increasing phosphorus is caused by the decrease of $\mathrm{pH}$ value. The increasing phosphorous is caused by the activity of Lactobacillus sp bacteria that change glucose become lactic acid, so it changes the acidity.

- The last contribution is cow urine because based on the result of calculation, it has influence in $\mathrm{pH}$ value because cow urine contains nitrogen, phosporous, and pottasium. [18] stated that cattle urine has made the plant (maize yield) to be the second highest compared to other urine such as human urine and goat urine. In his study, $\mathrm{pH}$ value of urine before being applied in the soil is 9.6 and the $\mathrm{pH}$ value of soil before applying urin on soil is 4.6. After doing a research, there is a change on the $\mathrm{pH}$ value on the soil which becomes 4.9. It means that cow urine can influence the $\mathrm{pH}$ value

\section{E. Signal Noise to Ratio Calculation}

The result of signal noise to ratio in this study can be shown in the Table VI.

TABLE VI: SIGNAL NOISE TO RATIO

\begin{tabular}{ccccc}
\hline \hline & O & B & C & D \\
\hline Level 1 & $\mathbf{6 . 7 5 1 2}$ & 6.3510 & $\mathbf{7 . 0 5 3 5}$ & 6.6763 \\
\hline Level 2 & 6.3646 & 6.3141 & 6.4529 & 6.3633 \\
\hline Level 3 & 6.6520 & $\mathbf{7 . 1 0 2 7}$ & 6.2614 & $\mathbf{6 . 7 2 8 1}$ \\
\hline Different & 6.2654 & 7.0657 & 5.6609 & 6.4152 \\
\hline Rank & 1 & 3 & 1 & 3 \\
\hline & A1 & B3 & C1 & D3 \\
\hline \hline
\end{tabular}

Based on Table VI it is revealed the output of SNR calculation from four factors three levels. The optimum composition based on the $\mathrm{pH}$ value are A1-B3-C1-D3. Factor A (Cow urine) with level 1 is $1000 \mathrm{ml}$, Factor B (Probiotic Em4) with level 3 is $6 \mathrm{ml}$, Factor C (Goat Dung) with level 1 is 500 gram, and Factor D (Spices) with level 3 is 30 gram.

The selected composition of A1 based on the signal noise ratio calculation. It gets the $\mathrm{pH}$ value of $\mathrm{A}$ with level 1, which was choosen because the signal noise ratio is using the best nominal. Therefore, it chooses the $\mathrm{pH}$ value close to 7 . It chooses 6.7512 and that the other factors have the same ways to get the result. The choice of factor A1 is $1000 \mathrm{ml}$ of cow urine, 500 gram of dung and B3 of $6 \mathrm{ml}$ probiotic EM4 because microorganism decomposes the organic material optimally if the nutrient for microorganism from molasses and nitrogen from cow urine and dung is fulfilled. The ratio of cow urine, dung and probiotic EM4 should be balanced otherwise the microorganism cannot obtain the nitrogen from the composition (cow urine and dung) and sufficient nutritional needs as the material for helping to decompose the organic material. Therefore, the fermentation process is slower than before [19]. Getting 30 gram of spices is the optimum content of nutrition for growing and developing plants. In addition, the optimum composition that has been obtained from noise signal to ratio calculation is in accordance with national $\mathrm{pH}$ standard values.

\section{F. Experiment Confirmation}

The result of experiment confirmation can be shown on the Table VII below

TABLE VII: EXPERIMENT CONFIRMATION

\begin{tabular}{cc}
\hline \multicolumn{2}{c}{ TABLE VII: EXPERIMENT CONFIRMATION } \\
\hline DF & 2 \\
\hline $\boldsymbol{t}$ table & 2.7764 \\
\hline $\boldsymbol{t}$ calculation & 44.600 \\
\hline \hline
\end{tabular}

It uses the independent sample $t$ test with significant level of 0,05 . The result found that $t$ calculation is more than that of $t$ table, therefore $44.600>2.7764$. It means that there is significant difference with the existing composition. In other words, the proposed composition of organic liquid fertilizer 
is better composition.

\section{CONCLUSION}

It can be concluded as follow:

1. The optimum composition of organic liquid fertilizer is $\mathrm{A} 1, \mathrm{~B} 3, \mathrm{C} 1$, and $\mathrm{D} 3$ which $\mathrm{pH}$ value is $7 . \mathrm{A} 1$ is $1000 \mathrm{ml}$ of cow urine, then $\mathrm{B} 3$ is $6 \mathrm{ml}$ of probiotic EM4, C1 is 500 gram of goat dung and the D3 is 30 grams of spices

2. The composition of organic liquid fertilizer developed is valid to differ significantly with the existing organic liquid fertilizer at $5 \%$ of a significant level.

\section{REFERENCES}

[1] C. L. D. Norman, Fertilizer and Their Uses, Agriculture Extension Service The University of Tennessee, 2012.

[2] Merriam Webster. (2017). [Online]. Available: https://www.merriam webster.com/dictionary/organic

[3] S. Govere, B. Madziwa, and P. Mahlatini, "The nutrient content of organic liquid fertilizers in zimbabwe," International Journal of Modern Engineering Research, vol. 1, no. 1, pp. 196-202, 2011.

[4] J. Chen, "The combined use of chemical and organic fertilizers and / or biofertilizer for crop growth and soil fertility the rhizosphere of the using chemical and organic," pp. 1-9, 2006

[5] G. A. Sopha and T. S. Uhan, "Mustard ( Brassica Juncea L ) Cultivation," vol. 5, no. 1, pp. 39-44, 2013.

[6] B. T. Davis, Fertilizer and pH, March 2009, pp. 1-7.

[7] N. Jayamangkala, P. Sutigoolabud, J. Inthasan, and S. Sakhonwasee, "The effect of organic fertilizers on growth and yield of broccoli ( Brassica oleracea L . var . italica Plenck cv. Top,” vol. 10, no.1, pp. 9-14, 2015

[8] U. B. Nazarbek, A. A. Kadirbayeva, and M. Z. Aitureev, Development of the Composition and Method of Producing a Liquid Complex Fertilizers With a Stabilizing Additive, 2017.

[9] N. W. Setyanto, L. Riawati, and R. P. Lukodono, "Desain eksperimen taguchi untuk meningkatkan kualitas pupuk organik berbahan baku kotoran kelinci," vol. 2, no. 2, pp. 32-36, 2014.
[10] G. S. Peace, Taguchi Methods, Canada: Addision Wesly Publishing Company, 1993.

[11] P. J. Ross, Taguchi Technique for Quality Engineering, Singapore, 1996.

[12] G. William, Cochran, and M. C. Gertrude, Experimental Design, New York: John Wiley \& Sons, 1992

[13] I. Soejanto, Desain Eksperimen Dengan Metode Taguchi, Graha Ilmu, Yogyakarta, 2009.

[14] F. S. Steven, "Analysis of variance: The fundamental concepts," vol 17 , no. 2, pp. 27-38, 2009.

[15] M. T. Michael, P. David, C. S. David, and J. M. Martinko, Brock Microbiology of Microorganisms, San Francisco: Benjamin Cummings publishing, 2011

[16] R. A. Wijaksono, R. Subiantoro, and B. Utoyo, "Pengaruh lama fermentasi pada kualitas pupuk kandang kambing ( effect of fermentation duration on goat manure quality," vol. 4, no. 2, 88-96, 2016.

[17] J. C. Barker, S. C. Hodges, F. R. Walls, and C. Services, 2002 North Carolina Agricultural Chemicals Manual Livestock Manure Production Rates And Nutrient Content Fertilizer Supplement Has Come Full Circle. Before The Ii, Farmers Routinely Used Manure To Complement A Good Chapter X-Fertilizer Use, pp. 1-4, 2002.

[18] N. Resources, A. History, and F. Length, "Effect of different urine sources on soil chemical properties and maize yield in Abakaliki, Southeastern Nigeria," vol. 3, pp. 31-36, 2005.

[19] K. A. Wijaya, Nutrisi Tanaman sebagai Penentu Kualitas Hasil dan Resistensi Alami Tanaman, Prestasi Pustaka, Jakarta, 2008,

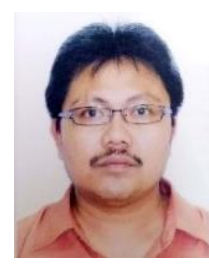

Hartomo Soewardi is a senior lecturer of the Industrial Engineering Department, Faculty of Industrial Technology, Islamic University of Indonesia, Yogyakarta, Indonesia. He was born in Banjarnegara on October 8, 1968. Currently he is $\mathrm{PhD}$ in engineering design and manufacture. His teaching and research interest are industrial ergonomic design, product design, management and quality design.

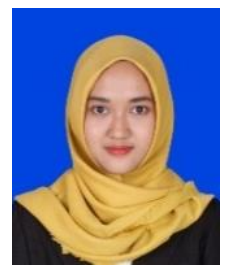

Raizsa Laksmita graduated with a bachelor degree a the Department of Industrial Engineering, Faculty of Industrial Technology, Islamic University of Indonesia in 2018. Her research interest is in quality control and management. 